\title{
Biodegradability of Formulated Enzymatic Solution: An Alternative Waste Reduction System
}

\author{
Miguel A. Santos', Danilet Vi M. Mendoza1, Rembrandth Vermeer M. De Guzman1, \\ Arneil G. Gabriel ${ }^{2}$ \\ ${ }^{1}$ Department of Chemistry and Environmental Science, College of Arts and Sciences, Nueva Ecija University of Science and \\ Technology, Cabanatuan City, Philippines \\ ${ }^{2}$ Department of Public Administration, Nueva Ecija University of Science and Technology, Cabanatuan City, Philippines \\ Email: opats14@yahoo.com
}

How to cite this paper: Santos, M.A., Mendoza, D.V.M., De Guzman, R.V.M. and Gabriel, A.G. (2017) Biodegradability of Formulated Enzymatic Solution: An Alternative Waste Reduction System. Open Journal of Ecology, 7, 300-308. https://doi.org/10.4236/oje.2017.74021

Received: January 25, 2017

Accepted: April 27, 2017

Published: April 30, 2017

Copyright ( 92017 by authors and Scientific Research Publishing Inc. This work is licensed under the Creative Commons Attribution International License (CC BY 4.0).

http://creativecommons.org/licenses/by/4.0/ (c) $\underset{\mathrm{EY}}{\text { (i) Open Access }}$

\begin{abstract}
Solid waste and air pollution are never ending environmental problems that can be partially solved by turning waste into useful bio-products. In this study, enzymatic solutions were developed by formulating enzymatic solutions from fish intestines and fruit peels. This aimed to help in biodegradation of organic solid wastes. Organic waste samples were treated with formulated enzymatic solutions for 7 days in aerated set-up for aerobic degradation. Biodegradability and odor of the waste samples were compared with commercial enzymatic solution. Determination of evolved carbon dioxide $\left(\mathrm{CO}_{2}\right)$ using gravimetric analysis (GA) was used to determine the percent biodegradability, Dt, of organic solid waste and odor-ranking method was used to determine the odor intensity of the organic waste samples. The result showed that the weight loss and percentage biodegradability of organic waste sample treated with formulated enzymatic solution is comparable with that of the commercial enzymatic solution. In terms of odor intensity, waste treated with the product, formulated enzymatic solution (FES) is also comparable to the waste treated with commercial enzymatic solution. Thus, implying that the developed FES is as efficient as that of the commercial enzymatic solution. These significant results will be helpful to future researchers in providing ways on improving the degradation of organic solid waste and mitigating the increasing glitches on our environment. Enzyme kinetics, physical and chemical properties studies of the solution were recommended for future researchers to accurately determine the effectiveness of the formulated enzymatic solution in the degradation of organic solid waste.
\end{abstract}

\section{Keywords}

Biodegradability, Formulated Enzymatic Solution, Waste Reduction 


\section{Introduction}

Cabanatuan City is considered as the economic heart of Nueva Ecija and is the focus of a metropolitan area of more than 300,000 people. Cabanatuan City residents, industrial and business establishments generated tons of garbage every day. Around $50 \%$ of which is biodegradable $35 \%$ recyclable and $15 \%$ residual. To address the growing problem of waste disposal, the City Government of Cabanatuan instituted ways of improving its existing dumpsites and transfer facility stations.

The former dumpsite in Valle Cruz, Cabanatuan City was closed to give way to its rehabilitation aimed at removing odorous pollution that is affecting the residents within and around the vicinity. These pollutants are mostly organic solid wastes, which have the highest percentage amount based on the previous waste analysis characterization system. These solid wastes are non-soluble materials that were discarded in a solid or semi-solid form. The semi-solid form of waste has the quality of both solid and liquid- like sludge.

Geographically, Valle Cruz dumpsite is a residential and agricultural area where emission of odorous pollutants poses grave effects on the health of the residents. Extension of the said facility to accommodate extra tons of wastes costs large amount of taxpayer's money and land conversion causes social and economic nuances. A more viable solution is the use of alternative means of waste reduction and anti-pollution technology, where the application of enzymatic solutions can be of great advantage. Extracellular enzymatic solutions can hydrolyze and digest insoluble organic waste [1].

Enzymatic solutions are natural, nontoxic substances that use enzymes that help the bacteria to digest organic materials directly. Enzymatic solutions are formulated specifically to dispose of soils safely, economically and rapidly [2] [3] [4]. They contain the necessary quality and quantity of specific enzyme systems, both aerobic and anaerobic bacteria, and microbial nutrient. Enzymatic solution works quickly around 2 weeks [5] and efficiently in the digestion of chemical and organic waste with no odor or noxious gas emissions. The micro-organism and right type of enzymes break the waste apart and the bacteria itself converts this waste into two basic compounds: carbon dioxide and water as indicated by the $\mathrm{C} / \mathrm{N}$ ratio [6]. This resulted in faster degradation of wastes with minimal residual component, and the absence of foul odors [7] [8] [9], thus making it a great candidate for obtaining waste disposal method that is environmentally and economically viable [10]. Moreover, the uses of enzyme solutions make the composting process of biodegradation of organic waste as self sustaining due to the soluble organic matter that forms and act as fuel for microorganisms for further degradation [11]. Aquatic organisms such as fish have a vast array of diversified genetic material that makes it a great source of different enzymes [12].

This study aimed to develop formulated enzymatic solution (FES) from fish intestines and fruit peels that could aid in biodegradation of organic wastes comparable with commercial enzymatic solutions based on the amount of $\mathrm{CO}_{2}$ evolved by and the weight loss of the organic wastes treated with different de- 
veloped FES from fish intestines and fruit peels and compare the biodegradation efficiency of the best formulated enzymatic solution with that of commercial enzymatic solution based on the amount of $\mathrm{CO}_{2}$ evolved by organic wastes, weight decrease of organic wastes and result of odor survey test. Lastly, it aimed to determine the biodegradability, $\mathrm{Dt}$, of the formulated enzymatic solution.

\section{Methodology}

\subsection{Experimental}

The true experimental method of research using CRD- pre-test-post-test design [13] was used in conducting the study.

In preparing the commercial enzymatic solution, $41.70 \mathrm{ml}$ of commercial enzymatic solution was diluted in 1.25 liters of distilled water based on the product label.

Equal grams of mango and banana peels where mixed and from that mixture, $321 \mathrm{~g}$ of waste was taken and mixed with $107 \mathrm{ml}$ molasses and $1 \mathrm{~L}$ of water in a 2 $\mathrm{L}$ container and then fermented for 3 months for the experimental enzymatic solutions. After the fermentation period, the solution was filtered and analyzed for the corresponding parameters; $\mathrm{pH}$ and $\mathrm{BOD}$ (biological oxygen demand). After the laboratory analysis dilution was adjusted to $\mathrm{pH} 7$, about $8 \mathrm{ml}$ of the solution was diluted to 1.9 liters distilled water. Same procedure was also applied with the use of fish intestines as a substitute of fruit peels to make enzymatic solution with the dilution of $2 \mathrm{ml}$ solution in $1.2 \mathrm{~L}$ of distilled water.

The prepared enzymatic solutions (experimental) made from fruit peels and fish intestines were mixed to determine the optimal mixture that would produce better result in bio-decomposition and odor reduction of organic solid waste. There were 5 formulations prepared: Formulation 1, a mixture of fruit peels (25\%) and fish intestines (75\%); formulation 2, a mixture of fish intestines (25\%) and fruit peels (75\%); formulation 3, a mixture of fish intestines (50\%) and fruit peels (50\%); formulation 4, an enzymatic solution composed of fruit peels (100\%); formulation 5, an enzymatic solution composed of fish intestines (100\%).

The amount of carbon dioxide evolved was determined by gravimetric analysis. From the air compressor, a rubber hose was connected to the carbon dioxide trap which contains soda lime to remove the carbon dioxide from the continuous flow of air (Figure 1). A humidifier was used to give enough moisture responsible for the degradation of organic waste. The suction flask/pet bottle that contains water was connected to the $1 \mathrm{~L}$ suction flask/pet bottle containing $200 \mathrm{~g}$ of organic waste and then connected to the dehumidifying trap which contains silica gel to remove the air moisture before going to the carbon dioxide absorbing column to avoid the increased in weight of carbon dioxide trap by moisture increase. The dehumidifying trap was connected to the $\mathrm{CO}_{2}$ absorbing column that contains $80 \mathrm{ml}$ of soda lime and soda talc mixture. This served as the absorbent of the carbon dioxide released by the bottle containing organic waste. The $\mathrm{CO}_{2}$ absorbing columns were weighed every 24 hours of aeration, the air flow was set to $14 \mathrm{~L} /$ hour [14]. 


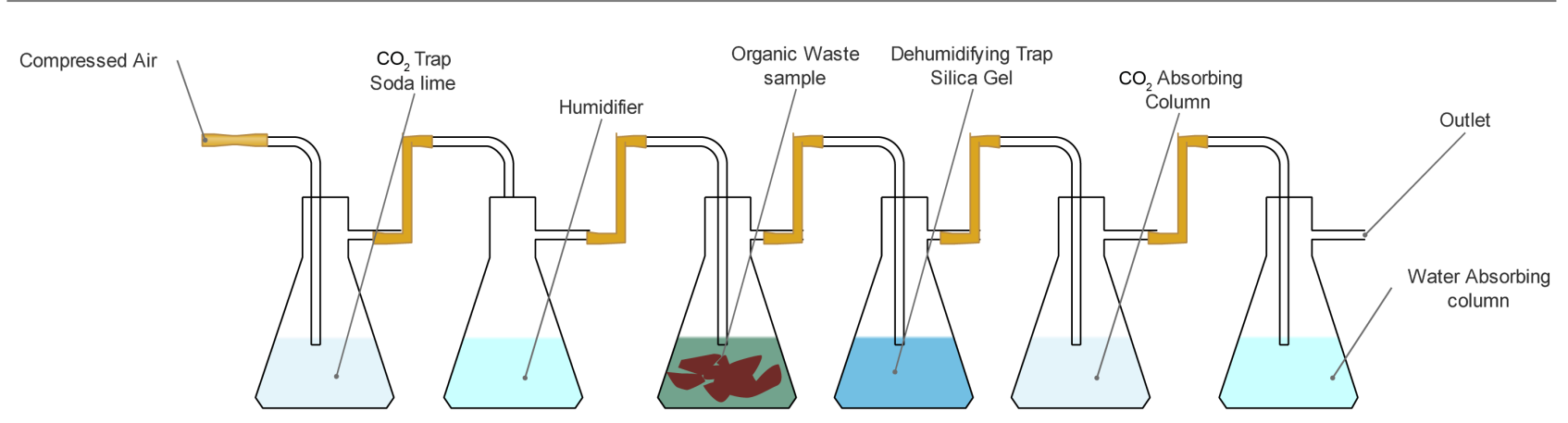

Figure 1. Set-up for determination of evolved carbon dioxide.

The mass of the evaporating dish was recorded, followed by the grinding of the test specimen using a laboratory blender. The specimen was added to the evaporating dish and weighted. After recording the mass of the evaporating dish with the test specimen, it was then oven-dried uncovered for at least $6 \mathrm{~h}$ at $250^{\circ} \mathrm{C}$ until there was no change in mass of the sample in excess of 1 hour. The test specimen was removed at the oven and placed in a desiccator for 5 minutes taking down the mass of the oven-dried test specimen. The percentage weight loss was calculated by subtracting the initial weight initial weight from the final dry weight taken from the moisture content determination result over initial weight multiplied by 100 percent.

$\%$ weight loss $=($ initial weight - final weight $) /$ initial weight $\times 100$

\subsection{Odor Survey}

During the test, the 20 panelists sniffed the prepared samples starting from the sample (a) to sample ( $g$ ) absorbed via cotton balls. The arrangement was not revealed to the panelist to avoid bias. The panelists were ask to rate the samples based on the odor intensity referencing scale standard practice (Table 1). The result from the survey test was tallied to determine the difference of the odor intensity of the different samples [15].

\section{Biodegradability Determination}

$$
D_{t}=\frac{\sum\left(\mathrm{CO}_{2}\right)_{T}^{t}-\sum\left(\mathrm{CO}_{2}\right)_{B}^{t}}{T h \mathrm{CO}_{2}} \times 100
$$

where:

$\sum\left(\mathrm{CO}_{2}\right)_{T}^{t}$ is the cumulative amount of carbon dioxide, in grams, evolved in test vessel between the start of the test and time;

$\sum\left(\mathrm{CO}_{2}\right)_{B}^{t}$ is the mean cumulative amount of carbon dioxide, in grams, evolved in the blank vessel between the start of the test and time $t$, and

$\mathrm{ThCO}_{2}$ is the theoretical amount of carbon dioxide, in grams, evolved by test material [16].

A stop gap approach for composting in solid waste estimation based on a formula developed in the 1950s and at A5TM D2974-87 Standard Test Methods for Moisture, Ash, and OM of Peat and Other Organic Soils was utilized to 
Table 1. Odor intensity referencing scale standard practice.

\begin{tabular}{ccc}
\hline \multirow{2}{*}{ Odor Intensity } & \multicolumn{2}{c}{ Scale } \\
\cline { 2 - 3 } & Numerical & Characteristic \\
\hline No odor & 1 & Faint and not irritating \\
Normal & 2 & Weak and a little annoying intensity of smell \\
Moderately strong & 3 & Noticeable and annoying odor \\
Strong & 4 & Tough and very annoying intensity \\
Very strong & 5 & Extremely exasperating odor \\
\hline
\end{tabular}

determine the carbon content as indicated by [17].

For the moisture determination, the mass of the evaporating dish was recorded, followed by the grinding of the test specimen using a laboratory blender. The specimen was added to the evaporating dish and weighted. After recording the mass of the evaporating dish with the test specimen it was then oven dried uncovered for at least $6 \mathrm{~h}$ at $250^{\circ} \mathrm{C}$ until there was no change in mass of the sample in excess of 1 hour. The test specimen was removed from the oven and placed in desiccators for 5 minutes.

The mass of the covered evaporating dish was recorded, and then the ovendried test specimen was placed in the dish taking into consideration the mass of the dish and specimen. The cover was removed and placed the dish into the muffle furnace. Gradually, the temperature in the furnace was set to $440^{\circ} \mathrm{C}$ and held until the specimen has no change of mass after a further period of heating. Afterwards, the specimen was cooled into the desiccators and then recorded the final mass. This was done in order to determine the ash content.

\section{Results and Discussion}

\subsection{Amount of $\mathrm{CO}_{2}$ Evolved by Organic Waste per Day Using Different Formulated Enzymatic Solutions}

Fish intestines contain enzymes that facilitate digestion, absorption and assimilation of molecules like proteins and lipids [18] [19] [20] [21]. Thus it can degrade organic waste and transform it into carbon dioxide and water. Organic waste that contains dried leaves was enclosed in plant cell walls that make it hard to degrade causing long time degradation. Fruit peels contain plant cell wall degrading enzymes that aid in the degradation process. Fruit peels usually contain xylanase, polygalacturonase, cellulase and $\alpha$-amylase [22] [23] [24] [25]. In this study, amount of carbon dioxide evolved per day was determined for the different enzyme solutions formulated. As shown in Figure 2, the formulation 3 (F3) (50\% fruit peels and 50\% fish intestines) has the highest increased amount of evolved $\mathrm{CO}_{2}$ per day with about $1.96 \mathrm{~g}$ in 7 days and reached its peak $(0.5 \mathrm{~g})$ on day 2. However, on day 5 it falls gradually into $0.4 \mathrm{~g}$ and $0.26 \mathrm{~g}$ at day 7 , respectively. It can also be noted that among the developed FES, F3 reached the greatest amount of $\mathrm{CO}_{2}$ evolved within the least number of elapsed time. 


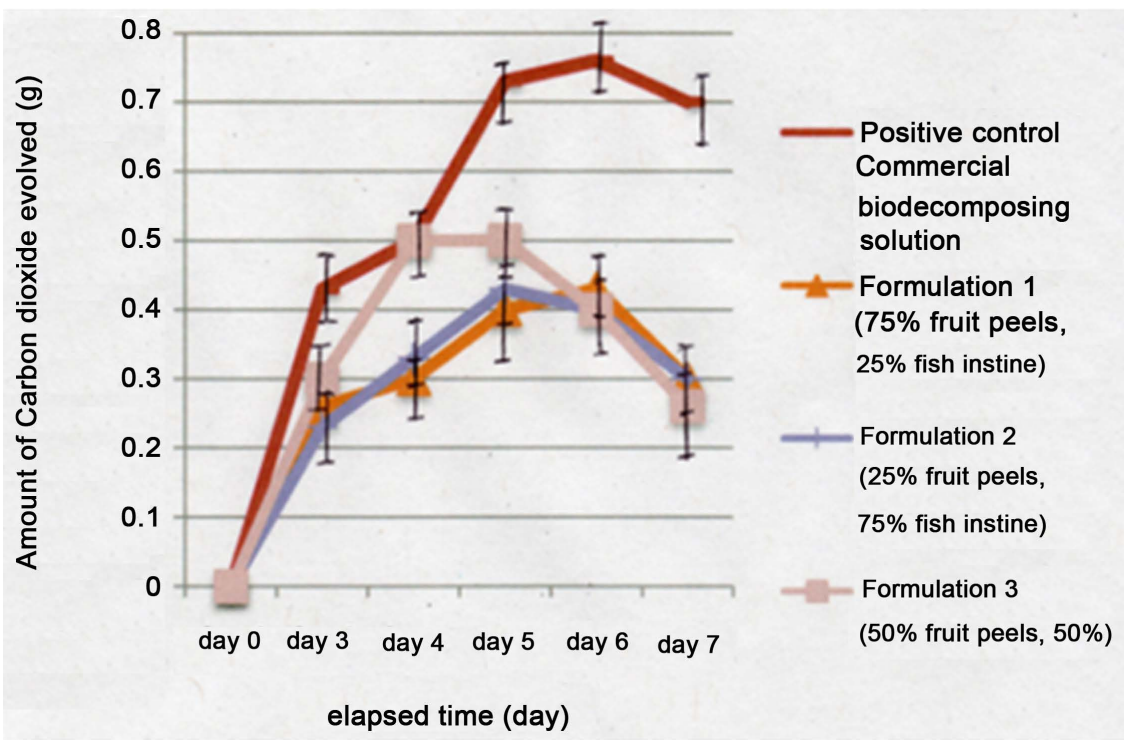

Figure 2. Amount of carbon dioxide evolved/day.

\subsection{Weight Decrease of Organic Waste per Day of the Formulated Enzymatic Solutions}

The organic waste sample applied with F3 (50\% fruit peels, 50\% fish intestines) has the greatest decreased in weight from day 0 to day 7 as shown in Figure 3. Since F3 yielded the highest amount of $\mathrm{CO}_{2}$ within the least number of days and the one with the greatest decrease in weight throughout the treatment, it was considered as the best formulation. Thus, the biodegradation efficiency of F3 was compared with that of the commercial enzymatic solution throughout the study.

\subsection{Biodegradability Efficiency}

The treatment of organic waste with F3 resulted to a percentage weight loss of $98.45 \%$ in 7 days which was slightly lower than the organic waste sample treated with the commercial enzymatic solution. To support the comparison, statistical analysis was done. The t-test results of total evolved $\mathrm{CO}_{2}$ and percentage weight loss which indicates that there was no significant difference between the commercial solution and F3 since the computed $t$-stat value is lower than the critical value. Thus, it can be noted that the biodegradability efficiency of the F3 is comparable with the commercial enzymatic solution in terms of these parameters.

The organic waste sample applied with F3 has a percentage biodegradability of 0.71 with about 505.75 milligram per kilogram per day. Organic wastes on the average has a percent biodegradability of $0.1-0.7$. This attainment of maximum percent biodegradability of the organic waste sample may be attributed to the treatment made.

\subsection{Odor Survey Result}

The organic waste sample applied with the commercial enzyme solution has a 


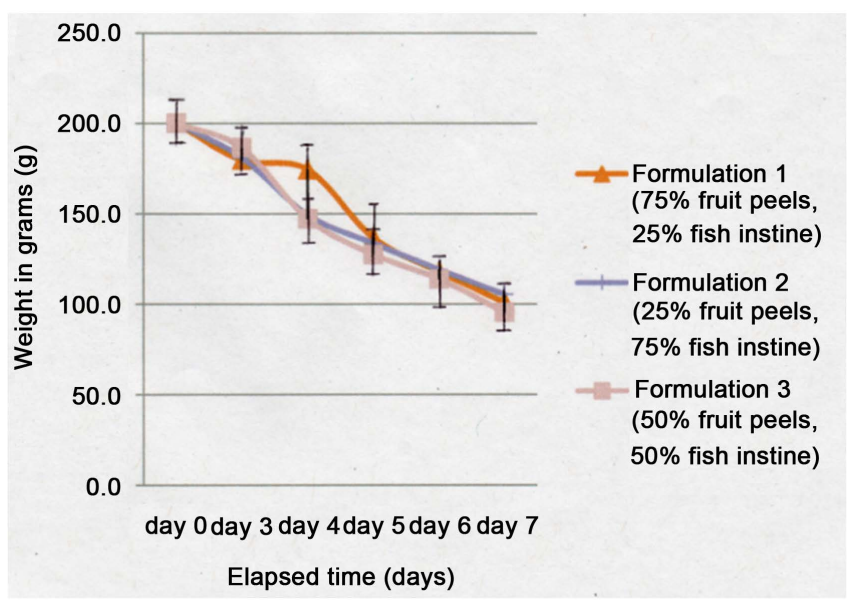

Figure 3. Decrease in weight of organic waste per day.

weighted mean of 2.7 which falls under normal odor. Commercial enzyme solution contains microbes which produces enzyme essential for odor reduction of organic solid waste. On the other hand, F3 has a weighted mean of 2.8 that also falls under the same description as having normal odor. Fruit peels contain enzymes that exhibit inhibition against gram positive and gram negative bacteria [26] [27] [28] [29]. Proliferation of these bacteria is the one responsible for the foul odor of organic waste. Thus, the application of enzymatic solution formulated resulted in normal acceptable odor of organic waste.

The $t$ test results of odor survey indicate that there was no significant difference between the commercial enzymatic solution and F3 since the $t$ stat is lower than the $t$ critical value. Thus, it can be noted that the use of the developed FES comprising of fruit peels and fish intestines was comparable with the commercial enzymatic solution in terms of odor reduction upon degradation of organic waste.

\section{Conclusion}

Enzymatic solutions formulated from fish intestines and fruit peels may be developed to assist in biodegradation of organic wastes. Formulated enzymatic solution made from $50 \%$ fruit peels and $50 \%$ fish intestines, $\mathrm{F} 3$, is comparable with the commercial enzymatic solution based on the amount of evolved $\mathrm{CO}_{2}$, weight loss of organic sample and odor survey test as supported by statistical analysis. The organic waste sample applied with the most effective formulation has a percentage biodegradability of 0.71 with about 505.75 milligram per kilogram per day. This maximized percent biodegradability may be attributed to the treatment of the formulated enzymatic solution. Thus the enzymatic solution formulated can maximize the decomposition and reduce the release of unpleasant odor of organic waste comparable with commercial enzyme solution.

\section{Acknowledgements}

The authors wish to thank the NEUST Administration, faculty and staff especially those under the College of Arts and Sciences for their support. 


\section{References}

[1] Zhang, B., He, P., Lü, F., Shao, L. and Wang, P. (2007) Extracellular Enzyme Activities during Regulated Hydrolysis of High-Solid Organic Wastes. Water Research, 41, 4468-4478. https://doi.org/10.1016/j.watres.2007.06.061

[2] Ayuso, M., Hernandez, T., Garcia, C. and Pascual, J. (1996) Biochemical and Chemical-Structural Characterization of Different Organic Materials Used as $\mathrm{Ma}$ nures. Bioresource Technology, 57, 201-207. https://doi.org/10.1016/0960-8524(96)00070-3

[3] Castaldi, P., Garau, G. and Melis, P. (2004) Influence of Compost from Sea Weeds on Heavy Metal Dynamics in the Soil-Plant System. Fresenius Environmental Bulletin, 13, 1322-1328.

[4] Esse, P., Buerkert, A., Hiernaux, P. and Assa, A. (2001) Decomposition of and Nutrient Release from Ruminant Manure on Acid Sandy Soils in the Sahelian Zone of Niger, West Africa. Agriculture, Ecosystems \& Environment, 83, 55-63. https://doi.org/10.1016/S0167-8809(00)00264-4

[5] Castaldi, P., Garau, G. and Melis, P. (2008) Maturity Assessment of Compost from Municipal Solid Waste through the Study of Enzyme Activities and Water-Soluble Fractions. Waste Management, 28, 534-540. https://doi.org/10.1016/j.wasman.2007.02.002

[6] Raut, M., William, S.P., Bhattacharyya, J., Chakrabarti, T. and Devotta, S. (2008) Microbial Dynamics and Enzyme Activities during Rapid Composting of Municipal Solid Waste-A Compost Maturity Analysis Perspective. Bioresource Technology, 99, 6512-6519. https://doi.org/10.1016/j.biortech.2007.11.030

[7] Mondini, C., Fornasier, F. and Sinicco, T. (2004) Enzymatic Activity as a Parameter for the Characterization of the Composting Process. Soil Biology and Biochemistry, 36, 1587-1594. https://doi.org/10.1016/j.soilbio.2004.07.008

[8] Munnoli, P.M. (2013) Management Industrial Organic Solid Waste through Vermi-Culture Bio Technology with Special Reference to Microorganisms.

[9] Sarkar, P., Meghvanshi, M. and Singh, R. (2011) Microbial Consortium: A New Approach in Effective Degradation of Organic Kitchen Wastes. International Journal of Environmental Health Research, 2, 170. https://doi.org/10.7763/ijesd.2011.v2.118

[10] Veeken, A. and Hamelers, B. (2002) Sources of $\mathrm{Cd}, \mathrm{Cu}, \mathrm{Pb}$ and $\mathrm{Zn}$ in Biowaste. Science of the Total Environment, 300, 87-98. https://doi.org/10.1016/S0048-9697(01)01103-2

[11] Benitez, E., Nogales, R., Elvira, C., Masciandaro, G. and Ceccanti, B. (1999) Enzyme Activities as Indicators of the Stabilization of Sewage Sludges Composting with $E i_{\text {- }}$ senia foetida. Bioresource Technology, 67, 297-303. https://doi.org/10.1016/S0960-8524(98)00117-5

[12] Shahidi, F. and Kamil, Y.J. (2001) Enzymes from Fish and Aquatic Invertebrates and Their Application in the Food Industry. Trends in Food Science and Technology, 12, 435-464. https://doi.org/10.1016/S0924-2244(02)00021-3

[13] Crano, W.D., Brewer, M.B. and Lac, A. (2014) Principles and Methods of Social Research. Routledge, London.

[14] Bezerra, R.P., Borba, F.K.S.L., Moreira, K.A., Lima-Filho, J.L., Porto, A.L.F. and Chaves, A.C. (2006) Extraction of Amylase from Fermentation Broth in Poly (Ethylene Glycol) Salt Aqueous Two-Phase System. Brazilian Archives of Biology and Technology, 49, 547-555. https://doi.org/10.1590/S1516-89132006000500003

[15] Nazim, F. and Meera, V. (2013) Treatment of Synthetic Greywater Using 5\% and 
10\% Garbage Enzyme Solution. Bonfring International Journal of Industrial Engineering and Management Science, 3, 111. https://doi.org/10.9756/bijiems.4733

[16] Adhikari, B.K., Trémier, A., Barrington, S. and Martinez, J. (2013) Biodegradability of $\mathrm{Mu}$ Nicipal Organic Waste: A Respirometric Test. Waste Biomass Valorization, 4, 331-340. https://doi.org/10.1007/s12649-012-9135-5

[17] Brummer, V., et al. (2014) Enzymatic Hydrolysis of Pretreated Waste Paper-Source of Raw Material for Production of Liquid Biofuels. Bioresource Technology, 152, 543-547. https://doi.org/10.1016/j.biortech.2013.11.030

[18] Kolkovski, S. (2001) Digestive Enzymes in Fish Larvae and Juveniles-Implications and Applications To Formulated Diets. Aquaculture, 200, 181-201. https://doi.org/10.1016/S0044-8486(01)00700-1

[19] Nayak, S.K. (2010) Role of Gastrointestinal Microbiota in Fish. Aquaculture Research, 41, 1553-1573. https://doi.org/10.1111/j.1365-2109.2010.02546.x

[20] Ray, A., Ghosh, K. and Ringø, E. (2012) Enzyme-Producing Bacteria Isolated from Fish Gut: A Review. Aquaculture Research, 18, 465-492.

https://doi.org/10.1111/j.1365-2095.2012.00943.x

[21] Samaranayaka, A.G., Kitts, D.D. and Li-Chan, E.C. (2010) Antioxidative and Angioten Sin-I-Converting Enzyme Inhibitory Potential of a Pacific Hake (Merluccius productus) Fish Protein Hydrolysate Subjected to Simulated Gastrointestinal Digestion and Caco-2 Cell Permeation. Journal of Agricultural and Food Chemistry, 58, 1535-1542. https://doi.org/10.1021/jf9033199

[22] Al-Hindi, R.R., Al-Najada, A.R. and Mohamed, S.A. (2011) Isolation and Identification of Some Fruit Spoilage Fungi: Screening of Plant Cell Wall Degrading Enzymes. African Journal of Microbiology Research, 5, 443-448.

[23] Kuhad, R.C., Gupta, R. and Singh, A. (2011) Microbial Cellulases and Their Industrial Applications. Enzyme Research, 2011.

[24] Puri, M., Sharma, D. and Barrow, C.J. (2012) Nzyme-Assisted Extraction of Bioactives from Plants. Trends in Biotechnology, 30, 37-44. https://doi.org/10.1016/j.tibtech.2011.06.014

[25] van den Brink, J. and de Vries, R.P. (2011) Fungal Enzyme Sets for Plant Polysaccharide Deg Radation. Applied Microbiology and Biotechnology, 91, 1477. https://doi.org/10.1007/s00253-011-3473-2

[26] Abdullah, N., Zulkifli, K.S., Abdullah, A., Aziman, N. and Kamarudin, W. (2012) Assessment on the Antioxidant and Antibacterial Activities of Selected Fruit Peels. International Journal of ChemTech Research, 4, 1534-1542.

[27] Fawole, O.A., Makunga, N.P. and Opara, U.L. (2012) Antibacterial, Antioxidant and Tyrosinase-Inhibition Activities of Pomegranate Fruit Peel Methanolic Extract. BMC Complementary and Alternative Medicine, 12, 200. https://doi.org/10.1186/1472-6882-12-200

[28] Settanni, L., et al. (2012) Inhibition of Foodborne Pathogen Bacteria by Essential Oils Extracted from Citrus Fruits Cultivated in Sicily. Food Control, 26, 326-330. https://doi.org/10.1016/j.foodcont.2012.01.050

[29] Wang, Y., Huang, S., Shao, S., Qian, L. and Xu, P. (2012) Studies on Bioactivities of Tea (Camellia sinensis L.) Fruit Peel Extracts: Antioxidant Activity and Inhibitory Potential Against $\alpha$-Glucosidase and $\alpha$-Amylase In Vitro. Industrial Crops and Products, 37, 520-526. https://doi.org/10.1016/j.indcrop.2011.07.031 
Submit or recommend next manuscript to SCIRP and we will provide best service for you:

Accepting pre-submission inquiries through Email, Facebook, LinkedIn, Twitter, etc. A wide selection of journals (inclusive of 9 subjects, more than 200 journals)

Providing 24-hour high-quality service

User-friendly online submission system

Fair and swift peer-review system

Efficient typesetting and proofreading procedure

Display of the result of downloads and visits, as well as the number of cited articles Maximum dissemination of your research work

Submit your manuscript at: http://papersubmission.scirp.org/

Or contact oje@scirp.org 